\title{
Learning, Curriculum Monitoring and Evaluation for Decision Making
}

\author{
Linda Caroline Messakh, Ulil Hartono, M. V. Roesminingsih \\ Department of Educational Management \\ Universitas Negeri Surabaya \\ Surabaya, Indonesia \\ linda.caroline90@gmail.com
}

\begin{abstract}
Decision making process is a part of improvement on higher education quality assurance. It can be gained from the result of Monitoring and Evaluation in Learning and Curriculum. This research conducting to evaluate the implementation of learning and curriculum monitoring and evaluation for Decision Making. This research was using qualitative approach with CIPP model (Context, Input, Process, Product). The result of this research show that the problems of learning and curriculum monitoring and evaluation was (1) context component shows purpose and preparation is well, (2) input of this program is courses list, schedule and instruments was well prepared but the instrument needs to be updated, (3) process component finds that the number of auditors was limited, and physical evidence is not well documented, (4) product is the result of monitoring and evaluation and follow-up of it, the result follow up was not performed.
\end{abstract}

Keywords-decision making; higher education quality assurance; monitoring and evaluation

\section{INTRODUCTION}

Decision or decide was formed from Latin, de that is off, and caedo that is to cut. So decide can be interpreted as cut off or a the activity of selecting various alternatives that can be chosen [1]. Another opinion states, decision making can be interpreted as the selection of a series of actions from two or more alternatives [2]. The purpose of decision making itself is to solve a problem or avoid problems that might arise in the future to fulfill the better situation.

Decision making according to George R. Terry is based on the following five things [3]: intuition and feelings from decision makers when making decisions, experience that has an impact on decision makers, facts of information obtained by decision makers, authority owned by the decision maker (the higher the authority, the greater the decision taken), the logic of understanding from the results of observations of decision makers.

Each type of decision making, both at various levels of the organization, programmed or not and under any circumstances, of course requires sufficient information so that decisions are made to be of high quality and reduce the level of risk as low as possible. The existence of high-quality information does not guarantee the production of a good decision, but without highquality information, it certainly produces bad decisions. Information is not a fact, either in the form of numbers, verbal descriptions, images or other codes, in this case information is a collection of facts that are processed into something more meaningful and can be presented for the decision making process [4].

The researcher chose to observe the decision-making process at the Surabaya State University Postgraduate based on the results of the Internal Quality Audit, specifically Monitoring and Evaluation as part of the higher education quality assurance system in this research. Quality has become a subject of much discussion everywhere now. Actually, there is no standard of quality that can describe all kind of quality in all subject2. Although there is no single standard for measuring the quality of all things, there are still some similarities in quality measurement in several elements [5]: customer expectations that must be fulfilled or even exceeded by service / goods providers, products, services, people, processes and services / goods provider environment, it is dynamic based on time and conditions.

Quality assurance in higher education means services provided by universities to students, alumni, users of graduates, and parents of students as customers [6]. The customer certainly has an expectation of the services provided by the college. The products produced are including the customers themselves, namely college alumni. Services provided include every process in universities and humans are all lecturers and staff of higher education.

The Ministry of Higher Education in ensuring that higher education reaches the national standard of higher education makes the higher education quality assurance system. This statement is according to the Republic of Indonesia Minister of Research, Technology and Higher Education Regulation Number 62 (2016) About the Higher Education Quality Assurance System. According to this regulation, the higher education quality assurance system is a systemic activity to improve the quality of higher education in a planned and sustainable manner. The higher education quality assurance system aims to ensure the fulfillment of Higher Education Standards consistently, so that the quality culture develops.

There are two kinds of higher education quality assurance systems, internal and external. The internal higher education quality assurance system is a systemic activity in the quality assurance of higher education by each university in an autonomous manner to control and improve the implementation of higher education in a planned and 
sustainable manner. It has a work cycle set namely the establishment, implementation, evaluation, control and improvement of the standards of Higher Education. SPMI activities are implemented in all aspects of higher education, both academic and non-academic.

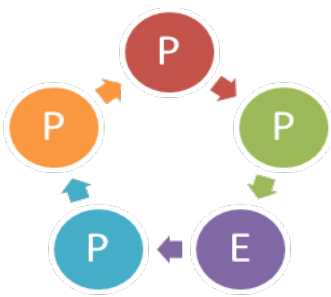

$\mathrm{P}=$ Higher Education Standard Determination

$\mathrm{P}=$ Higher Education Standard Implementation

$\mathrm{E}=$ Evaluation of Implementation

$\mathrm{P}=$ Controlling of Implementation

$\mathrm{P}=$ Higher Education Standard Improvement

Fig. 1. Cycle of higher education internal quality assurance system. Resource: [1]

Curriculum and learning monitoring and evaluation is a part of internal quality audit activities especially in learning process. This is in the evaluation cycle of higher education internal quality assurance system.

This activity begins with an opening meeting to provide explanations and instructions regarding the implementation. Furthermore, according to the schedule that has been prepared, the auditors will examine the learning process and curriculum that has taken place in the lecture. The monitoring and evaluation team members will make a report of the results of the monitoring and evaluation and will be sent to the quality assurance group to be verified [7].

There are 2 types of monitoring and evaluation results, namely findings and observations [7]. Observation (OB) means that the implementation of the higher education standard is in accordance with the standards, but there are still improvements that need to be made in the future. While the results in the form of findings mean, there are errors in the implementation of standards. The findings can be minor findings, which means there are small errors and major findings, which means big mistakes and even irregularities occur.

The findings that have been recorded must eventually be followed up with improvements needed. If repairs have been made, the auditor and the quality assurance group will give approval and keep proof of the improvement [7]. During the monitoring and evaluation, the results of the monitoring and evaluation activities in the form of findings from nonconformities can be used for decision making by the head of the study program, so that follow up actions can be taken so that the study program meets higher education quality standards [7].

Unlike Europe, Indonesia and all country in Asia doesn't have to accomplish two standards of education. In Europe all of the country has to attain national standard of education on those country and also the Europe standard of education [8]. So, in Indonesia, we only need the internal and external national quality assurance activities results for improvement directly.

According to these statements, we could imply that the research objective is to evaluate the implementation of learning and curriculum monitoring and evaluation for Decision Making, according to context, input, process and product component.

\section{METHOD}

This study uses a qualitative approach, namely field research in the implementation of curriculum monitoring and evaluation activities and learning for decision making. According to Sugiyono, qualitative research is a research method used to examine natural objects, as opposed to experiments. This research was conducted on objects that develop as they are, not manipulated by researchers and the presence of researchers does not really affect the dynamics of the object. Qualitative approaches are often referred to as naturalistic methods because they are carried out in natural conditions [9].

Evaluation model in this research was CIPP that is context, input, process and product evaluation. According to Nana Sudjana and Ibrahim, CIPP can be translated into for dimension, that is context that evaluate the background of preparation process include vision and aims of this program, input that evaluate the input used for this program, process that evaluate all the implementation of this program and product for the result of the process [10].

Data analysis used in this researched was data reduction, data display and verification and conclusion-making. The study was conducted at the postgraduate of Universitas Negeri Surabaya. In particular, the research was conducted at Quality Assurance Group postgraduate program of Universitas Negeri Surabaya.

\section{RESULTS AND DISCUSSION}

\section{A. Context}

Universitas Negeri Surabaya postgraduate quality assurance group has an organizational structure that specifically oversees AMI activities and the Curriculum and Learning Monev, namely the monitoring and evaluation division. There are several tasks of this division, that is facing the upgrade and surveillance of ISO, do monitoring and evaluation process in learning and curriculum activities, coordinate the schedule to auditors, giving a brief explanation to auditor, update the data needs, planning the next monitoring and evaluation program and create the report of the results.

All of the task and the purpose of this monitoring and evaluation in learning and curriculum were written on the website of postgraduate Universitas Negeri Surabaya, while the schedule and all the explanation of preparation is held on a private meeting and not published explicitly.

The auditors of monitoring and evaluation or referred to as monitoring officers are members of the appointed Surabaya State University Quality Assurance Cluster. Monitoring and evaluation activities begin with a preliminary meeting between 
the Chair of the Quality Assurance Group and the heads of study programs at the Surabaya State University Postgraduate Program. The purpose of this meeting is to set a timetable for time, space, courses, lecturers to be monitored, and evaluators for each study program with the right schedule.

\section{B. Input}

The input needs for this process is the list of courses that needs to be evaluated, schedule for monitoring and evaluation, and also instrument that consist of question list for monitoring and evaluation. The courses list was prepared by all of heads of the major, the schedule and question list for instrument was prepared by the administration staff of quality assurance group of postgraduate Universitas Negeri Surabaya.

From the interview with the administration staff and several auditors, the instrument that has been prepared was rarely to be changed because it can be assumed that the instrument can be used for all of major.

The monitoring and evaluation schedule must also be updated based on the lecturer lecture schedule to be audited and also based on the time availability of the supervisors. If the communication schedule changes that have to be very flexible are hampered, then a schedule error can be experienced by the auditor or lecturer concerned.

\section{Process}

The number of monitoring members is quite limited, so that each study program is only 1 lecturer who will be monitored, in each semester. Then the observer will follow the course while giving an assessment of the implementation of learning by the lecturer concerned.

The physical evidence prepared by the lecturer in the course is not well documented, because in reporting the results of the monitoring and evaluation, the observer does not need to attach the physical evidence that has been examined, only needs to check if there is physical evidence and record the problems. The physical evidence attached is only physical evidence of the findings that were followed up. Even though the physical evidence can still be used for other quality assurance activities, such as ISO audits and accreditation.

\section{Product}

The results of the monitoring and evaluation from the auditor are sometimes not immediately returned to the administrative staff of the quality assurance group, so that the recapitulation of the results of monitoring and evaluation (monev) by the quality assurance group cannot be immediately carried out. The monev document carried by the auditor is still a paper document, so the possibility of the papers being lost is still very large. If the recapitulation of the results of the monitoring and evaluation is not immediately carried out, then follow-up also cannot be done immediately.

The follow-up of the results of the monitoring and evaluation at the postgraduate of the Surabaya state university was also not conducted immediately after the monitoring and evaluation ended. After the recapitulation of the monitoring and evaluation results, the administrator only sends the results to the Surabaya State University Quality Assurance Center without waiting for follow-up from the study program on any available findings. Even though this follow-up is a series of cycles of the higher education internal quality assurance system in the steps of higher education standards control. The following figure illustrates the current system of curriculum monitoring and evaluation work.

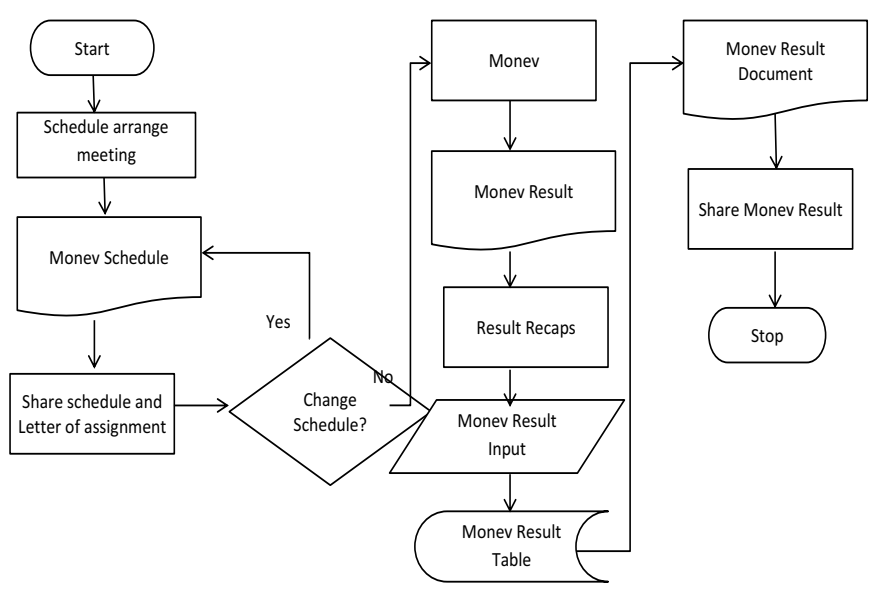

Fig. 2. Flowchart Surabaya State University Postgraduate Quality Assurance Group

Beerkens state that there are two stage on internal quality assurance activities that is document check and visitation [11]. Both stages were well managed in Surabaya State University Postgraduate Quality Assurance Group.

The other research on Prince Sultan University founds that if all staff and lecturers realized the importance of internal quality assurance activities then this system could be well managed [12]. This is accordance to the findings of this research, that not all the academic staff realizes the importance of internal quality assurance, so sometimes they result sheet not immediately returned to the administrative staff of the quality assurance group.

The students also can get the advantages from good system of quality assurance in university. It improves learning experience, and prepared the students for facing the real world out there. That's why the university with great quality assurance system can have great number of students [13]. It proves that good internal system of quality assurance in university can support the external system of quality assurance [14].

\section{CONCLUSION}

So, that it can be concluded that in the context component the purpose and preparation of this monitoring and evaluation is stated well, whether in website and in private meeting. The schedule that needs to be adjusted effectively because it has to be matched with the auditors and the lecturers.

The conclusion that can be stated from input component is that the input of monitoring and evaluation process that is courses list, schedule and instruments was well prepared by the 
heads of major and administration staff. The instrument is not changed in several years because it still can be used for all major in postgraduate Universitas Negeri Surabaya, so it needs to be evaluated, that might be needs several updates.

Process component finds that the number of auditors was limited, namely 8 people with a composition of 6 members of the quality assurance group and 2 members of the quality assurance unit, so that a system that saves time and energy (paperless) is needed for monitoring and evaluation at 23 study programs at the Surabaya State University Postgraduate Program. Physical evidences that needs to be documented for the needs of the future external and internal quality assurance activities

Product of this monitoring and evaluation was the result of monitoring and evaluation. Sometimes the auditor is not immediately give it back to the administration staff, so the recapitulation cannot be performed immediately also. Result follow-up of non-conformity is not performed so the quality improvement cannot be performed as well.

The impact of curriculum and learning monitoring and evaluation on Post Graduate State University of Surabaya for decision-making was not well seen. From the context and input component, there are no big problems stated, but there are several problems in process and product component that impacted on decision-making for quality improvement. Because of the documentation of the physical evidence is not well performed, so it cannot be used to another internal quality assurance process other than monitoring and evaluation. The product that is the result of monitoring and evaluation that should be used to following up the improvement was not done, so there was no decision made to improve the quality of learning and curriculum according to monitoring and evaluation results.

For the following suggestion, to build an information system that has the ability to manage all of the monitoring process. The system should show the result and the suggestion of non-conformity result, so the follow up process for decisionmaking in improvement of quality can be done. It can help all the decision maker to fix all the bugs in learning and curriculum activities and also improve it to achieve the standard. There also research that doing this and successfully implement information system on assessment [15], so it can be done to here.

\section{REFERENCES}

[1] E. Rochaety, P. Rahayuningsih, and P. G. Yanti, "Sistem Informasi Manajemen Pendidikan," Jakarta Bumi Aksara, 2006.

[2] H. A. Al-Tarawneh, "The main factors beyond decision making," $J$ Manag. Res., vol. 4, no. 1, pp. 1-23, 2012.

[3] G. R. Terry, "Prinsip-prinsip Manajemen, Jakarta," Bumi Aksara, 2013.

[4] W. Kumorotomo and S. A. Margono, Sistem informasi manajemen: dalam organisasi-organisasi publik. Gajah Mada University, 1994.

[5] S. Suyitno, "The enhancement of human resources through the implementation of total quality management at PR Prima in Malang, East Java-Indonesia,” J. Soc. Sci., vol. 5, pp. 557-565, 2016.

[6] N. Nurdin, "Quality Assurance in Higher Education," J. Educ. J. Manaj. Pendidik., vol. 7, no. 1, pp. 9-17, 2015.

[7] R. Hedwig, "Sistem Penjaminan Mutu di Perguruan Tinggi, Monitoring dan Evaluasi Internal,” ke-1., cet. ke-1. Yogyakarta Graha Ilmu, 2007.

[8] D. Blackstock et al., Internal Quality Assurance--Facing Common Challenges. ENQA Workshop Report 13. ERIC, 2010.

[9] M. P. K. Sugiono and P. Kuantitatif, "kualitatif dan R\&D," Bandung Alf., 2007.

[10] I. Nana Sudjana, "Penelitian dan Penilaian Pendidikan," Bandung Sinar Baru, 2004.

[11] M. Beerkens, "Evidence-based policy and higher education quality assurance: progress, pitfalls and promise," Eur. J. High. Educ., vol. 8, no. 3, pp. 272-287, 2018.

[12] S. Albaqami, "Implementing Quality Assurance in Saudi Arabia: A Comparison between the MESO and the MICRO Levels at PSU.," High. Educ. Stud., vol. 5, no. 3, pp. 66-81, 2015.

[13] A. Z. Ravasan, M. M. Mohammadi, and H. Hamidi, "An Investigation Into the Critical Success Factors of Implementing Information Technology Service Management Frameworks," in Corporate and Global Standardization Initiatives in Contemporary Society, IGI Global, 2018, pp. 200-218.

[14] K. H.-J. Chen and A. Y.-C. Hou, "Adopting self-accreditation in response to the diversity of higher education: quality assurance in Taiwan and its impact on institutions," Asia Pacific Educ. Rev., vol. 17, no. 1, pp. 1-11, 2016.

[15] D. Ozdemir and R. Loose, "Implementation of a quality assurance review system for the scalable development of online courses," Online J. Distance Learn. Adm., vol. 17, no. 1, p. 7, 2014. 